\title{
Global Financial Crisis: Macroeconomic Linkage to Pakistan's Agriculture
}

\author{
Professor Dr. Abdul Latif \\ Chairman Department of Management Sciences \\ Islamia University Bahawalpur, Pakistan \\ E-mail: drabdullatif@hotmail.com \\ Muhammad Suhail Nazar \\ Assistant Professor, Deptt: of Management Sciences \\ Islamia University, Bahawalpur, Pakistan \\ E-mail: Suhail_nazar@yahoo.com \\ Dr. Maqsood Zia Shah \\ Assistant Professor, Deptt: of Statistics \\ SALU-Khairpur, Pakistan \\ Faiz. M. Shaikh \\ Assistant Professor, Deptt: Agri:Economics \\ SZABAC-Dokri-Larkana, Sindh, Pakistan \\ E-mail: faizanmy2000@hotmail.com
}

Received: September 19, 2010

Accepted: January 10, 2011

doi:10.5539/ass.v7n7p90

\begin{abstract}
This research investigates the impact of Global Financial Crisis Macro economic linkages to Pakistan's Agriculture. Macroeconomic shocks can impact agriculture more strongly than factors that affect the sector directly. Data were collected from various secondary sources. It was revealed that recent Global financial crisis has negative impact on the Trade growth in Pakistan. It also affects the Price, production, consumption and trade. It was further revealed that Pakistan's exports have fallen substantially, through mainly because of a drop in the world trade prices rather than export volume.
\end{abstract}

Keywords: Global, Financial, Crisis, Macroeconomic, Linkage

\section{Introduction}

Pakistan is facing problems because of the Global financial crisis with fast depleting international reserves there is a growing fear that the country may be forced into defaulting on its foreign obligations. It was because of this fear that on October 6, both Standard \& Poor and Moody's, two of the world's largest rating agencies, downgraded Pakistani bonds. One such bond will run out of its term early next year and the investors have begun to fear whether Pakistan will be able to pay them back. Government data shows that inflation adjusted house prices nationwide on average essentially reached from 1953-1995 (Baker.D, et. al., 2002). Robert shiller constructed a data series going back to 1895 which showed that real house prices had been essentially unchanged for one hundred years prior to 1995 .

It now appears that the financial crises that have gripped America and Europe will also affect the real economies of these countries like Pakistan. Most experts now believe that America and Europe at this time stand at the threshold of deep recessions. The first signs of these have already begun to appear. In September, Americans lost 160,000 jobs; it is expected that by the end of the year there will be a reduction of one million jobs in the United 
States. Job losses result in declines in spending. Consumer spending is the main engine of growth in the United States. If it declines significantly, the economy will go into recession. That is likely to happen. When an economy is in recession, there is a negative impact on imports. We will see a fairly large reduction in the American imports of the developing world, the country that will be affected most severely will be China which depends on exports to the United States to drive its trade oriented economy. The affect on china will be felt by a number of countries in its neighbourhood who have become important suppliers of parts and components to the rapidly transforming Chinese production system. While China has a large trade surplus with the United States, it has begun to run trade deficits with many East Asian countries. Trade, in other words, will transmit to many developing countries the shocks of the current financial crisis in the western world. Global financial crisis has negative impact on the rural poverty in Sindh (F.M.Shaikh et, al 2009)

\section{Data Collection Methodology}

Data were collected with secondary sources, annual reports, of various trade, and agriculture, and Statistical reports, Economic survey of Pakistan various issues and analysis by using E-views statistical software.

The above table 1 elaborate the linkage between agriculture growth to macroeconomic variables during the global financial crisis, as demonstrated by the financial crisis, are the exchange rate, consumer income, and interest rate.

\section{Exchange rate}

Currency depreciation lowered the exchange rate between the Global crisis. The reduced exchange rate raised consumer and producer prices for foods stuff, as well as prices for trade able agriculture inputs. The increase in domestic prices reduced food demand and consumption. The effect of currency depreciation on agricultural output depended on how it changed producer's term of trade.

\section{Income}

The recent global financial crisis has reduced consumer's income (table1) where GDP contribution from Agriculture sector which is continuously, declining. Income related to agriculture declines. Falling income reduced consumers demand for food stuff. The degree to which demand dropped for specific foodstuff depended on their income elasticity of demand.

\section{Interest Rate}

Capital flight raised interest rates in the Global financial crisis, reduced the availability of credit, lowered capital investment in Agriculture, and raised input costs if producers had to borrow to finance input purchases. The isolated effect was to worsen producer's terms of trade.

\section{Combined Effects of the Linkages}

The fall in the exchange rate and decreasing consumer income both caused consumption of drop. On the other hand, currency depreciation and in the rise in the interest rate could result in either rise or fall in production depending on whether the two events or worsen producers in terms of trade. For the most agricultural commodities trade able inputs are not a fraction of total input volume terms, prices and interest charges are no a dominant part of total production costs.

As a result, the term of trade of most producers in most crisis has improved after 2009. The global financial crisis of many variables that affect agriculture production in particular whether for crops, it is difficult to isolate quantitatively the positive effect on the crisis, the production towards declines in the agriculture sector and market prices fall down in Rice.

\section{Linkages to Pakistani Agriculture}

The fall in Agricultural demand in the global financial crisis, reduce prices of Rice in the world market, farmers expected price fall down and majority of the Rice farmers have affected due to the decrease in the price of rice in the world market.

The fall in the price of Rice raised consumption and had the isolated effects of worsening producer's terms of trade and reducing production. However the currency depreciation has also affect on the income of farmers as well as on trade.

\section{Global Financial Crisis Effects on Agricultural Trade}

Global financial crisis has increased Pakistan's agricultural imports and decreased exports in value terms. The rise in the agricultural imports appears to be a response to the drop in world commodity prices expressed in 
Pak-Rupees. Likewise Pakistan's exports have fallen largely because of the crisis-induced drop in the World demand and accompanying decline in the Pakistan's producers and export prices.

The major implication even a depreciation in the Pak-rupee would not increase the export demand from time to time politician and economists given arguments regarding the devaluation of Pak-Rupee because of increasing export but this is not true in the reality.

\section{Conclusion}

Global financial crisis has affected the agricultural mainly through changes in the exchange rate, consumer income and interest rate. The Crisis impacts are evident in recent changes in agricultural trade. Based on trade data from 2008-2009-10 Pakistan's export fall down during the financial crisis and in 2009 trade was bit slow compared with 2007. Prices are fallen because demand for agricultural commodities has declined. The rise in the agricultural imports appears to be a response to the drop in world commodity prices expressed in Pak-Rupees. Likewise Pakistan's exports have fallen largely because of the crisis-induced drop in the World demand and accompanying decline in the Pakistan's producers and export prices. As a result, the term of trade of most producers in most crisis has improved after 2009. The global financial crisis of many variables that affect agriculture production in particular whether for crops, it is difficult to isolate quantitatively the positive effect on the crisis, the production towards declines in the agriculture sector and market prices fall down in Rice.

\section{References}

Aghevli, B.B. (1998). Asian Crisis causes and remedies. Paper presented in the Federal Reserve Bank of Chicago/IMF conference. Asia: An Analysis of Financial crisis, Chicago, October.

F.M.Shaikh \& Nazir Ahmed Gopang. (2009). Global Financial crisis and its impact on poverty in rural Sindh, Journal of Academic Research in Economics, Romania.

Fan. S, P. Hazel \& S, Throat. (1999). Linkages between in Rural Pakistan, Research Report 110, International food Policy Research Institute, Washington DC.

Gaiha, R. (1989). Poverty, Agricultural Production and Price Fluctuations in Rural Pakistan A Reformulation. Cambridge J. of Econ., 13 (June): 333-52.

Ghose, A.K. (1989). Rural Poverty and Relative Prices in Pakistan. Cambridge j. of Econ., 13 (June): 307-31.

Glick, R. (1998). Thoughts on the origins of the Asia Crisis: Impulses and propagation, paper presented at federal Reserve bank of Chicago/IMF conference. Asia: An Analysis of Financial crisis, Chicago, October.

Greene, W.H. (1993). Econometric Analysis. Englewood Cliffs NJ: Princeton- Hall, Inc.

Griffin, k. \& A.K. Ghose. (1979). Growth and Impoverishment in the Rural Areas of Asia. World Develop. 7 , (April/May): 36-84.

Krugman. (1998). What happened to Asia? Mimeo Massachusetts institute of technology, January.

Langley. (2000). Agriculture and trade reports: International Financial crisis and Agriculture. Economic research service March.

Schuh, G.E. (1974). The exchange rate and US agriculture. American J. of Economics, 56 (February): 1-13. 
Table 1. Macroeconomic Linkages to Agriculture trade in Pakistan

Macroeconomic Linkage variables

Agriculture Trade effect

\begin{tabular}{|l|l|l|l|l|l|l|}
\hline Year & $\begin{array}{l}\text { Exchange } \\
\text { Rate \% }\end{array}$ & GDP Growth \% & Interest rate & Imports & Export & Trade Balanced \\
\hline $\mathbf{2 0 0 7}$ & $\mathbf{6 0 . 0}$ & $\mathbf{2 1 . 9}$ & $\mathbf{6 0}$ & $28.225 \mathrm{~m}$ & $14.011 \mathrm{~m}$ & -14.214 \\
\hline $\mathbf{2 0 0 8}$ & $\mathbf{6 0 . 5}$ & $\mathbf{2 1 . 8}$ & $\mathbf{6 2 . 1}$ & 31.094 & 14.641 & -16.452 \\
\hline $\mathbf{2 0 0 9}$ & $\mathbf{8 0}$ & $\mathbf{2 1 . 7}$ & $\mathbf{8 0}$ & 26.412 & 13.770 & -12.642 \\
\hline $\mathbf{2 0 1 0 ( J u n e )}$ & $\mathbf{8 5 . 5}$ & $\mathbf{2 . 6 . 6}$ & $\mathbf{8 5 . 5}$ & 13.412 & 6.770 & -7.642 \\
\hline
\end{tabular}

Source: http://trade.ec.europa.eu/doclib/docs/2006/september/tradoc_113431.pdf

Table 2. Agriculture Growth Percent

\begin{tabular}{|l|l|l|l|}
\hline Year & Agriculture & Major Crops & Minor Crops \\
\hline $2002-03$ & $\mathbf{4 . 1}$ & $\mathbf{6 . 8}$ & $\mathbf{1 . 9}$ \\
\hline $2003-04$ & $\mathbf{2 . 4}$ & $\mathbf{1 . 7}$ & $\mathbf{3 . 9}$ \\
\hline $2004-05$ & $\mathbf{6 . 5}$ & $\mathbf{1 7 . 5}$ & $\mathbf{1 . 5}$ \\
\hline $2005-06$ & $\mathbf{6 . 3}$ & $\mathbf{- 3 . 9}$ & $\mathbf{0 . 4}$ \\
\hline $2006-07$ & $\mathbf{4 . 4}$ & $\mathbf{7 . 7}$ & $\mathbf{- 1 . 5}$ \\
\hline $2007-08$ & $\mathbf{1 . 1}$ & $\mathbf{- 6 . 4}$ & $\mathbf{1 0 . 9}$ \\
\hline $2008-09(\mathrm{P})$ & $\mathbf{4 . 7}$ & $\mathbf{7 . 7}$ & $\mathbf{3 . 6}$ \\
\hline
\end{tabular}

Source-Federal Bureau of Statistics-2009 